\title{
PENGARUH CITRA MEREK DAN KUALITAS PRODUK TERHADAP LOYALITAS MEREK PRODUK KOSMETIK WARDAH DI SURABAYA SELATAN
}

\author{
Dwi Ari Lestari ${ }^{1)}$, Nurhadi ${ }^{2)}$ \\ Universitas Pembangunan Nasional "Veteran" Jawa Timur \\ E-mail : Dwiarilestari953@gmail.com¹ ${ }^{1}$ nurhadi.ab@upnjatim.ac.id ${ }^{2}$
}

\begin{abstract}
This research aims to determine the joint effect of brand image and product quality and to analyze the effect of brand image and product quality on brand loyalty of Wardah cosmetic products in South Surabaya. The population used in this study are all consumers who use Wardah cosmetics in South Surabaya. The sample used in this study were 100 respondents using purposive sampling technique. The data collection technique of this research used a questionnaire. The data testing methods used are validity test, reliability test, classical assumption test, $t$ test, $f$ test, and multiple linear regression analysis. The results of the study can be seen that simultaneously and partially brand image and product quality have a positive and significant effect on brand loyalty of Wardah cosmetic products in South Surabaya.
\end{abstract}

Keywords: Brand Image, Product Quality, and Brand Loyalty.

Abstrak : Penelitian ini bertujuan untuk mengetahui pengaruh gabungan citra merek dan kualitas produk serta menganalisis pengaruh citra merek dan kualitas produk terhadap loyalitas merek produk kosmetik Wardah di Surabaya Selatan. Populasi yang digunakan dalam penelitian ini adalah seluruh konsumen yang menggunakan kosmetik Wardah di Surabaya Selatan. Sampel yang digunakan dalam penelitian ini sebanyak 100 responden dengan menggunakan teknik purposive sampling. Teknik pengumpulan data penelitian ini menggunakan kuesioner. Metode pengujian data yang digunakan adalah uji validitas, uji reliabilitas, uji asumsi klasik, uji t, uji $\mathrm{f}$, dan analisis regresi linier berganda. Hasil penelitian dapat diketahui bahwa secara simultan dan parsial citra merek dan kualitas produk berpengaruh positif dan signifikan terhadap loyalitas merek produk kosmetik Wardah di Surabaya Selatan.

Kata Kunci : Citra Merek, Kualitas Produk, dan Loyalitas Merek.

\section{A. PENDAhuluan}

Di era globalisasi dan modernisasi saat ini, tingkat perekonomian di Indonesia telah mengalami banyak peningkatan. Setiap perusahaan harus mempertahankan produknya dengan menarik calon pelanggan lama atau pelanggan baru agar pelanggan tidak meninggalkan perusahaan untuk pindah ke perusahaan lain. Di sisi lain, perusahaan harus mampu mempertahankan loyalitas merek. Loyalitas terhadap merek produk merupakan konsep penting, terutama dalam kondisi persaingan yang sangat ketat dengan pertumbuhan yang rendah. Merek memegang peranan penting dalam persaingan perusahaan, semakin kuat suatu merek di suatu sektor tertentu, maka semakin sulit bagi pesaing lain di sektor yang sama untuk masuk dan bersaing.

Merek ini akan mengusung nama sebuah produk yang memiliki kualitas tinggi, sehingga produk yang berkualitas semakin diminati atau dikenal oleh pelanggan. Oleh karena itu, kualitas produk merupakan salah satu faktor penting dalam menjalankan bisnis. Dimana kualitas produk akan menentukan tingkat kepuasan pelanggan bagi perusahaan. Berdasarkan Badan Pusat Statistik, jumlah penduduk Indonesia pada tahun 2019 mencapai 268 juta jiwa, angka ini terdiri dari penduduk perempuan sebanyak 133,42 juta jiwa. Dengan banyaknya penduduk perempuan, maka akan menjadi peluang besar bagi para produsen di perusahaan kosmetik. 
Perusahaan kosmetik akan menawarkan lebih banyak produk kepada konsumen. Banyak merek kosmetik dalam negeri yang beredar di pasaran dan memiliki kualitas dan keunggulan yang berbeda-beda, seperti salah satu merek kosmetik dalam negeri yaitu kosmetik Wardah. PT. Paragon Techonology And Innovation

telah membawa brand kosmetik Wardah sebagai brand lokal terbesar di Indonesia yang dikenal dengan brand image halalnya. Kosmetik Wardah dikeluarkan pada tahun 1985. Semakin banyak orang yang mengenal atau menggunakan merek kosmetik Wardah, semakin meningkat pula mereknya. Kosmetik Wardah yang banyak menggunakan akan mendapatkan Top Brand Award dimana Top Brand Award merupakan penghargaan yang diberikan kepada brand-brand terbaik yang dipilih oleh konsumen.

Merujuk data dari situs www.topbrand-award.com, pada tahun 2020 ini, kosmetik Wardah mendapatkan penghargaan top brand dapat dilihat tabel sebagai berikut :

\begin{tabular}{|c|c|c|c|c|c|c|}
\hline \multirow{2}{*}{ Merek } & \multicolumn{2}{|c|}{2018} & \multicolumn{2}{c|}{2019} & \multicolumn{2}{c|}{2020} \\
\cline { 2 - 7 } & TBI & TOP & TBI & TOP & TBI & TOP \\
\hline Wardah & $\mathbf{3 5 . 5 \%}$ & TOP & $\mathbf{3 3 . 6 \%}$ & TOP & $\mathbf{2 7 . 6 \%}$ & TOP \\
\hline Pixy & 14.1 & TOP & $10.1 \%$ & TOP & $10.8 \%$ & TOP \\
\hline Caring & - & & $5.5 \%$ & TOP & $7.5 \%$ & \\
\hline Maybeline & - & & $5.1 \%$ & & $4.7 \%$ & \\
\hline Viva & $8.6 \%$ & & $4.3 \%$ & & $4.3 \%$ & \\
\hline
\end{tabular}

Sumber : (https://www.topbrand-award.com), 2020

Berdasarkan uraian data top brand index diatas pada kosmetik wardah mendapatkan top brand index sebesar 27,6 persen untuk produk bedak padat yang menempati peringkat 1 dan disusul kosmetik pixy $(10,8 \%)$ di posisi 2 . Ini Kondisi tersebut menunjukkan bahwa konsumen membutuhkan kosmetik dalam kehidupan sehari-hari. Pada tahun 2019, kosmetik Wardah memiliki persentase indeks yang besar sebesar 33,6\% diikuti oleh Pixy sebesar 10,1\%. Meski kedua merek ini mengalami penurunan indeks di tahun 2020, kosmetik Wardah mengalami penurunan signifikan sebesar $6,0 \%$ sedangkan pixy cukup berhasil mempertahankan persentase indeks yang hanya turun $0,7 \%$.

Meski indeks top brand kosmetik Wardah pernah mengalami pasang surut, namun TBI tetap berada di kategori top brand award (TOP). Maka dengan segala strategi pemasaran kosmetik tersebut, Wardah tetap berusaha untuk memperebutkan posisi teratas dari merek kosmetik lainnya. Penurunan persentase indeks ini dapat menimbulkan permasalahan pada citra merek kosmetik Wardah yang dapat mempengaruhi loyalitas merek pada produk kosmetik Wardah.

Loyalitas merek merupakan perilaku positif seorang konsumen terhadap suatu merek yang mendorong konsumen untuk secara konsisten melakukan pembelian ulang terhadap merek tersebut (Febriyanto, 2007).

Loyalitas merek mencerminkan loyalitas pelanggan terhadap merek tertentu. Dharmayanti (2014), menyimpulkan bahwa citra merek dan kualitas yang dirasakan berpengaruh signifikan terhadap kepuasan pelanggan. Kepuasan pelanggan berpengaruh signifikan terhadap loyalitas pelanggan, sedangkan citra merek dan kualitas yang dirasakan berpengaruh tidak langsung terhadap loyalitas pelanggan.

Citra Merek berkaitan dengan sikap tentang kepercayaan pada suatu merek dan membantu mewakili persepsi informasi tentang merek itu sendiri. Hal ini dibuktikan dalam penelitian Ridho (2017) yang menyatakan bahwa citra merek suatu perusahaan berpengaruh terhadap tingkat kepuasan pelanggan. Citra merek adalah segala sesuatu yang berhubungan dengan merek yang ada di benak ingatan konsumen. Citra merek merupakan salah satu faktor terpenting yang harus diperhatikan perusahaan dalam menjaga loyalitas konsumen (Febriyanto, Djoko, Umin, 2021). 
Sondakh (2014) menyatakan bahwa citra merek tidak berpengaruh terhadap kepuasan pembelian, sehingga dimungkinkan ada variabel lain yang memperkuat atau memperlemah pengaruh citra merek terhadap kepuasan pembelian. Faktor lain yang dapat menciptakan kepuasan pelanggan adalah kualitas produk yang tinggi.

Kualitas produk menurut Hadi dalam Putri (2013) menyatakan bahwa kualitas produk yang sengit menuntut pemasar untuk dapat memberikan produk yang berkualitas dan mampu mengembangkan produk yang bermanfaat, variatif, dan inovatif sesuai dengan kebutuhan pasar dan harapan konsumen. Persepsi positif yang diciptakan oleh perusahaan melalui kualitas produknya menggambarkan citra merek produk yang baik di benak konsumen.

Menurut Suwarni (2011), kemampuan produk dalam memberikan pelayanan yang terbaik kepada pengguna akan memperkuat posisi atau posisi produk di benak konsumen sehingga memungkinkan konsumen untuk melakukan pilihan pertama jika akan melakukan pembelian. di masa depan. Salah satunya pada kosmetik wardah yang memiliki kualitas bagus di Indonesia.

Wardah mempunyai banyak jenis produk yang telah diproduksi, jenis dalam produk wardah memiliki kegunaan yang berbeda-beda. Wardah mempunyai produk secara keseluruhan kurang lebih memiliki 300 jenis produk seperti make up, skin care, hair care, dan body care. Produk wardah tersebut disesuaikan dengan warna kulit konsumen, sehingga konsumen bisa memahami atau memilih jenis produk sesuai dengan kulit masing-masing. Berikut ini tabel varain produk wardah :

\begin{tabular}{|c|c|c|}
\hline No & Jenis & Macam Produk \\
\hline \multirow{5}{*}{1} & \multirow{5}{*}{ Make Up } & Lipstik, Lipcream, Lip Tint \\
\hline & & Eyeshadow \\
\hline & & Pensil Alis \\
\hline & & BB Cream \\
\hline & & Foundation \\
\hline \multirow{6}{*}{2} & \multirow{6}{*}{ Skin Care } & Serum Wajah \\
\hline & & Suncreen \\
\hline & & Face Mask \\
\hline & & Nature Daily \\
\hline & & Cream Wardah \\
\hline & & Acne series \\
\hline \multirow{2}{*}{3} & \multirow{2}{*}{ Hair Care } & Shampo Wardah \\
\hline & & Conditioner \\
\hline \multirow{3}{*}{4} & \multirow{3}{*}{ Body Care } & Spa Series \\
\hline & & Lip care \\
\hline & & Scentsation \\
\hline
\end{tabular}

Sumber :https://www.wardahbeauty.com/

Dari tabel di atas dapat dilihat banyak jenis produk wardah mulai perawatan badan semua ada produknya. Produk wardah memiliki macam untuk jenis kulit konsumen dan memiliki kegunaan yang berbeda-beda. Mulai dari make up yang dapat mengubah wajah tampak cerah serta menjadi cantik, produk wardah dapat digunakan mulai usia remaja sampai dewasa karena bahan yang dibuat oleh wardah aman dan halal maka tidak berbahaya bagi kulit konsumen. Tetapi terkadang ada yang tidak cocok memakai kosmetik wardah, sehingga kosmetik wardah ini tergantung cocok atau tidaknya dalam 99 persen pengguna kosmetik wardah cocok memakai produk tersebut.

Pengaruh citra merek dan kualitas produk terhadap loyalitas merek produk kosmetik Wardah dapat dijadikan penelitian yang menarik, karena kosmetik merupakan produk penting bagi 
masyarakat di Indonesia khususnya di kota Surabaya yang dikenal dengan suhu panas yang tinggi yaitu antara $25^{\circ} \mathrm{C}-32^{\circ} \mathrm{C}$. Sehingga masyarakat Surabaya tentunya membutuhkan kosmetik untuk melindungi wajah dari sinar matahari. Dalam penelitian ini peneliti mengangkat citra merek dan kualitas produk yang mempengaruhi loyalitas merek, sehingga peneliti memberikan judul "Pengaruh Citra Merek dan Kualitas Produk Terhadap Loyalitas Merek Produk Kosmetik Wardah Di Surabaya Selatan".

Dengan demikian, rumusan masalah dalam penelitian ini adalah sebagai berikut: Apakah ada pengaruh citra merek dan kualitas produk secara bersama-sama terhadap loyalitas merek produk kosmetik Wardah?, Apakah ada pengaruh citra merek terhadap loyalitas merek produk kosmetik Wardah?, Apakah ada pengaruh kualitas produk terhadap loyalitas merek? produk wardah? Tujuan penelitian adalah: Untuk mengetahui pengaruh citra merek dan kualitas produk secara bersama-sama terhadap loyalitas merek produk kosmetik Wardah, Untuk mengetahui pengaruh citra merek terhadap loyalitas merek produk kosmetik Wardah, Untuk mengetahui pengaruh kualitas produk terhadap loyalitas merek Produk kosmetik Wardah.

\section{B. TINJAUAN PUSTAKA}

Pemasaran adalah aktivitas mengatur institusi, dan proses untuk menciptakan, mengomunikasikan, menyampaikan, dan mempertukarkan penawaran yang memiliki nilai bagi pelanggan, klien, mitra, dan masyarakat luas (Kotler dan Keller 2016:27). Loyalitas merek sangat penting bagi perusahaan karena dapat mempengaruhi berbagai aspek bisnis perusahaan, antara lain mengurangi biaya pemasaran, meningkatkan perdagangan, menarik pelanggan baru, memberikan waktu untuk merespon ancaman pesaing, dan mempertahankan kelangsungan hidup suatu perusahaan. Preferensi konsumen yang konsisten untuk melakukan pembelian merek yang sama pada kategori produk atau jasa tertentu. Loyalitas merek diukur dari sikap terhadap merek yang bersangkutan, tidak hanya dari pembelian berulang yang terus menerus (Schiffman dan Kanuk dalam Bastian 2014: 3).

Merek setia pada barang tahan lama atau bahan tahan lama dengan barang konsumsi atau barang konsumsi (Singh 2016:9). Sedangkan menurut Aaker dalam Atmadjaja (2017:5) adalah ukuran hubungan pelanggan terhadap suatu merek. Ukuran ini dapat memberikan gambaran tentang kemungkinan seorang pelanggan beralih ke produk lain, terutama pada merek yang mengalami perubahan baik harga maupun atribut lainnya. Menurut Rangkuti dalam Kusuma (2014), loyalitas merek dapat diukur melalui Behavior Measures, Measuring Switch Cosi, Measuring Satisfaction, dan Measuring Like Brand.

Citra Merek menggambarkan sifat ekstrinsik suatu produk atau jasa termasuk cara merek berusaha memenuhi kebutuhan psikologis atau sosial pelanggan. Menurut Kotler dan Keller (2013:270) citra merek adalah citra merek yang menggambarkan sifat ekstrinsik produk atau jasa, termasuk cara merek berusaha memenuhi kebutuhan psikologis atau sosial pelanggan. Dimensi utama pembentuk citra suatu merek terdapat pada Identitas Merek (brand identity), Kepribadian Merek (Brand Personality), Asosiasi Merek (Brand Association), Sikap dan Perilaku Merek (brand attitude and behavior), Manfaat dan Kompetensi Merek (Brand Benefit and Competence). Manfaat dan Keunggulan Merek).

Kualitas produk memberikan dorongan kepada konsumen untuk menjalin ikatan yang kuat dengan perusahaan. Konsumen akan senang jika kebutuhannya terpenuhi. ) kualitas produk adalah kemampuan suatu produk untuk menjalankan fungsinya, meliputi daya tahan produk, keandalan, akurasi, kemudahan pengoperasian dan perbaikan, serta atribut-atribut berharga lainnya (Kotler dan Armstrong (2012: 283).Sedangkan Mowen (2011: 90) ) kualitas produk adalah suatu proses evaluasi secara menyeluruh kepada pelanggan atas peningkatan kinerja suatu barang atau jasa Kualitas produk memberikan dorongan kepada konsumen untuk menjalin ikatan yang kuat dengan 
perusahaan Indikator Kualitas Produk menurut Nasution (2015: 03) yaitu Kinerja (Performance ), Features (Fitur), Reliability (keandalan), Conformance (Kesesuaian), Durability (Durability), Service Ability (Kemampuan Layanan), Aesthetics (Estetika), Perceived Quality (Percived Quality).

Berdasarkan deskripsi. Berdasarkan uraian tersebut, kerangka berpikir dalam penelitian ini dapat diuraikan sebagai berikut:

\section{Gambar 1 kerangka berpikir}

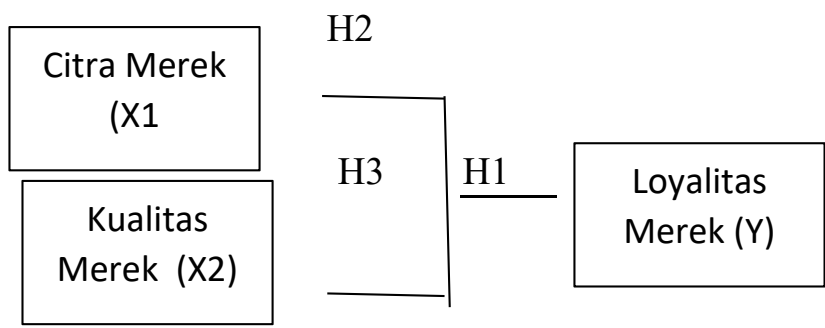

Gambar diatas menunjukkan bahwa Citra merek dan kualitas produk secara simultan berpengaruh signifikan terhadap loyalitas merek produk kosmetik wardah, serta Citra merek dan kualitas produk secara persial berpengaruh signifikan terhadap loyalitas merek produk kosmetik wardah.

\section{METODE PENELITIAN}

Penelitian ini menggunakan penelitian kuantitatif. Penelitian ini dilakukan dengan menyebarkan kuesioner kepada 100 responden yang pernah membeli atau menggunakan kosmetik wardah di kota Surabaya Selatan. Kuesioner disebarkan melalui media sosial berupa google from. Metode pengambilan sampel yang digunakan dalam penelitian ini adalah non-probability sampling, artinya semuanya tidak memberikan kesempatan atau peluang yang sama bagi setiap elemen atau anggota populasi untuk dipilih sebagai sampel. Sedangkan sampel penelitian yang digunakan dalam penelitian menggunakan teknik purposive sampling yaitu teknik pengambilan sampel untuk sumber data dengan pertimbangan tertentu (Sugiyono 2015:85). Dimana pertimbangan dalam penelitian ini adalah antara konsumen yang pernah membeli atau menggunakan kosmetik wardah di kota surabaya selatan.

Penelitian ini menggunakan tipe data primer, dimana penelitian ini akan menyebarkan kuesioner melalui media sosial berupa google from. Sumber data yang diperoleh dalam penelitian ini adalah hasil penyebaran kuesioner dari responden yang pernah membeli atau menggunakan kosmetik Wardah di Surabaya Selatan. Dari teknik pengumpulan data penelitian ini adalah penyebaran kuesioner yang dalam penelitian ini berisi identitas dan tanggapan sesuai dengan indikator yang diajukan dalam variabel yang diteliti meliputi citra merek, kualitas produk, dan loyalitas merek. Penelitian ini menggunakan teknik analisis data yaitu uji validitas, uji reliabilitas, uji asumsi klasik, uji hipotesis, dan uji analisis linier berganda.

\section{HASIL PENELITIAN DAN PEMBAHASAN}

Berdasarkan hasil kuesioner yang telah dibagikan sebelumnya, diketahui bahwa responden berdasarkan jenis kelamin adalah 4\% laki-laki dan 96\% perempuan. Responden berdasarkan usia sebagian besar berusia 21-30 tahun sebesar 30\%. Berdasarkan luasnya, sebagian besar berada di area pot sebesar $15 \%$. Responden berdasarkan pekerjaan sebagian besar adalah mahasiswa sebesar $42 \%$.

Penelitian ini menggunakan instrumen angket yang perlu dilakukan dengan menggunakan uji validitas dan reliabilitas. Variabel citra merek terdiri dari 9 pertanyaan kuesioner, variabel 
kualitas produk terdiri dari 8 pertanyaan kuesioner, dan variabel loyalitas merek terdiri dari 7 pertanyaan kuesioner.

Dapat dilihat bahwa data uji validitas dan reliabilitas terdapat pada tabel 2 dan tabel 3.

Tabel 2 Uji Validitas

\begin{tabular}{|c|c|c|}
\hline Variabel & Item & R hitung \\
\hline \multirow{9}{*}{ Citra Merek } & $\mathrm{X} 1.1$ & 0,669 \\
\hline & $\mathrm{X} 1.2$ & 0,661 \\
\hline & X1.3 & 0,856 \\
\hline & $\mathrm{X} 1.4$ & 0,772 \\
\hline & $\mathrm{X} 1.5$ & 0,83 \\
\hline & $\mathrm{X} 1.6$ & 0,785 \\
\hline & $\mathrm{X} 1.7$ & 0,696 \\
\hline & $\mathrm{X} 1.8$ & 0,787 \\
\hline & X1.9 & 0,814 \\
\hline \multirow{8}{*}{ Kualitas Produk } & $\mathrm{X} 2.1$ & 0.773 \\
\hline & $\mathrm{X} 2.2$ & 0.765 \\
\hline & $\mathrm{X} 2.3$ & 0.784 \\
\hline & $\mathrm{X} 2.4$ & 0.694 \\
\hline & $\mathrm{X} 2.5$ & 0.706 \\
\hline & $\mathrm{X} 2.6$ & 0.893 \\
\hline & $\mathrm{X} 2.7$ & 0.861 \\
\hline & $\mathrm{X} 2.8$ & 0.795 \\
\hline \multirow{7}{*}{ Loyalitas Konsumen } & Y.1 & 0.619 \\
\hline & Y.2 & 0.57 \\
\hline & Y.3 & 0.667 \\
\hline & Y.4 & 0.705 \\
\hline & Y.5 & 0.683 \\
\hline & Y.6 & 0.689 \\
\hline & Y.7 & 0.823 \\
\hline
\end{tabular}

Sumber: Data diolah, 2021

Tabel 3 Uji Realibilitas

\begin{tabular}{|c|c|c|}
\hline Variabel & Cronbach's Alpha & Keterangan \\
\hline Citra Merek (X1) & 0.908 & Reliabel \\
\hline Kualitas Produk (X2) & 0.908 & Reliabel \\
\hline Loyalitas Merek (Y) & 0.943 & Reliabel \\
\hline
\end{tabular}

Sumber: Data diolah,2021

Berdasarkan tabel di atas, semua pertanyaan angket pada variabel independen dan dependen dalam penelitian ini memiliki nilai $\mathrm{R}$ hitung $\geq \mathrm{R}$ tabel $(0,1946)$ yang akan dinyatakan valid. Sedangkan untuk uji reliabilitas dapat diketahui bahwa semua item pertanyaan menghasilkan nilai cronbach alpha yang lebih besar dari 0,6 sehingga semua variabel penelitian ini yaitu citra merek, kualitas produk, dan loyalitas merek dinyatakan reliabel.

Dalam analisis regresi linier berganda persyaratan harus dipenuhi. Uji normalitas menunjukkan nilai signifikansi $>0,05$ yaitu 0,2 maka dapat dinyatakan data berdistribusi normal. Uji multikolinearitas menunjukkan nilai VIF pada kedua variabel bebas $<10$ yaitu 2.577 untuk variabel citra merek dan kualitas produk, sehingga persamaan tersebut dapat disimpulkan bahwa tidak terdapat multikolinearitas pada semua variabel bebas tersebut. Uji heteroskedastisitas dengan scatterplot menunjukkan bahwa sebaran data tidak memiliki pola yang jelas seperti menyebar, 
menyempit, dan merata titik-titik di atas dan di bawah angka 0 pada sumbu Y. Berdasarkan hal tersebut dapat dikatakan bahwa data berdistribusi normal dan tidak terdapat gejala uji heteroskedastisitas. Uji autokorelasi menunjukkan $\mathrm{dU}<\mathrm{dW}<4-\mathrm{dU}$ adalah $1,7152 \leq 2,362 \leq 2$, 285 , sehingga dapat disimpulkan tidak terdapat autokorelasi.

Tabel 4. Uji Koefisien Determinasi

\begin{tabular}{ccccc}
\hline Model & $\mathrm{R}$ & $\mathrm{R}$ Square & $\begin{array}{c}\text { Adjusted R } \\
\text { Square }\end{array}$ & $\begin{array}{l}\text { Std. Error of } \\
\text { the Estimate }\end{array}$ \\
\hline \multicolumn{1}{c}{0,788} & 0,620 & 0,612 & 3.23270 \\
\hline Sumber: data diolah, 2021 & &
\end{tabular}

Uji kelayakan model dapat disimpulkan bahwa layak semua dimana hasil pengujian mendapatkan nilai Sig. F sebesar 0,000 atau dibawah taraf uji penelitian sehingga Ho ditolak. Hasil analisis untuk uji $\mathrm{F}$ dapat dilihat dibawah ini :

\begin{tabular}{llrrrr}
\hline Model & $\begin{array}{l}\text { Sum of } \\
\text { Squares }\end{array}$ & Df & $\begin{array}{c}\text { Mean } \\
\text { Square }\end{array}$ & F & Sig. \\
\hline Regression & 1656,277 & 2 & 828,139 & 79,245 & $.0,00$ \\
Residual & 1013,683 & 97 & 10.45 & & \\
\hline Total & 2669,96 & 99 & & & \\
\hline
\end{tabular}

Sumber: data diolah, 2021

Berdasarkan hasil perhitungan dengan menggunakan program SPSS 23, dapat diketahui nilai koefisien determinan sebesar 0,620. Besaran angka koefisien determinasi (R Square) sama dengan $62,0 \%$. Angka tersebut memiliki arti yaitu variabel citra merek (X1), kualitas produk (X2) dan loyalitas merek (Y) sebesar $62,0 \%$.

Pengujian hipotesis dilakukan dengan berdasarkan koefisien regresi dan nilai probabilitas. Dapat dilihat tabel 6 dibawah ini :

Tabel 6 Analisis Regresi Linier Berganda

\begin{tabular}{|c|c|c|c|c|c|}
\hline \multirow{2}{*}{ Model } & \multirow{2}{*}{$\begin{array}{c}\begin{array}{c}\text { Unstandardized } \\
\text { Coefficients }\end{array} \\
\text { B } \\
\end{array}$} & \multicolumn{2}{|c|}{$\begin{array}{l}\text { Standardized } \\
\text { Coefficients }\end{array}$} & \multirow[t]{2}{*}{$\mathrm{T}$} & \multirow{2}{*}{ Sig. } \\
\hline & & Std. Error & Beta & & \\
\hline (Constant) & $-7,077$ & 3,051 & & $-2,320$ & 0,022 \\
\hline Citra Merek & 0,433 & 0,113 & 0,386 & 3,845 & 0,000 \\
\hline Kualitas Produk & 0,551 & 0,124 & 0,448 & 4,459 & 0,000 \\
\hline
\end{tabular}

Sumber : data diolah, 2021 berikut :

Berdasarkan tabel diatas dapat dijelaskan bahwa dapat diperoleh persamaan regresi sebagai 


$$
\mathrm{Y}=-7,077+0,433+0,551+3,051
$$

Variabel citra merek (X1) memiliki nilai t hitung sebesar 3,845 $>\mathrm{t}$ tabel sebesar 1,983 dengan tingkat signifkansi $0,00<0,05$ hal ini menunjukkan adanya pengaruh positif dan signifikan secara parsial antara variabel bebas $(\mathrm{X} 1)$ dengan variabel terikat $(\mathrm{Y})$, sehingga dapat disimpulkan $\mathrm{H}_{0}$ ditolak dan $\mathrm{H}_{1}$ diterima. Variabel kualitas produk (X2) memiliki nilai t hitungan sebesar 4,459 $<\mathrm{t}$ tabel sebesar 1,983 dengan tingkat signifikansi 0,000 >0,05 maka $\mathrm{H}_{0}$ ditolak dan $\mathrm{H}_{3}$ diterima. Sehingga dapat disimpulkan bahwa secara parsial variabel bebas kualitas produk (X1) berpengaruh signifikan terhadap signifikan terhadap variabel terikat loyalitas merek (Y).

\section{PEMBAHASAN}

Penelitian ini menghasilkan temuan bahwa citra merek dan kualitas produk berpengaruh positif dan signifikan terhadap loyalitas merek sebagai berikut:

\section{Pengaruh Citra Merek terhadap Loyalitas Merek}

Berdasarkan hasil penelitian ini dinyatakan bahwa citra merek berpengaruh positif dan signifikan terhadap loyalitas merek. Jika suatu produk memiliki citra merek yang baik atau terkenal maka loyalitas merek yang dihasilkan akan kuat bagi kosmetik Wardah di Subaya Selatan.

Hal ini menunjukkan bahwa konsumen yang pernah membeli atau menggunakan kosmetik Wardah memperhatikan brand image kosmetik Wardah dan dapat dilihat dari hasil kuisioner bahwa variabel brand image yang terjadi pada kosmetik Wardah sudah benar, seperti adanya identitas merek yang jelas dari Wardah atau dikenal dengan halal. Sehingga citra merek yang baik maka loyalitas merek akan kuat.

Hasil penelitian ini mendukung penelitian Olivia Dinar Oktadiani, Nur Laily (2020), Ritmaratri Yola Vernadila, Sadari (2019) yang menjelaskan bahwa citra merek berpengaruh positif dan signifikan terhadap loyalitas pelanggan. Menurut Kotler dan Keller (2013:27), citra merek menggambarkan sifat ekstrinsik suatu produk atau jasa termasuk cara merek berusaha memenuhi kebutuhan psikologis atau sosial pelanggan.

Hasil penelitian ini menunjukkan bahwa citra merek berpengaruh positif signifikan terhadap loyalitas merek produk kosmetik Wardah di Surabaya Selatan.

\section{Pengaruh Kualitas Produk Terhadap Loyalitas Merek}

Kualitas produk berpengaruh positif dan signifikan terhadap loyalitas merek. Jika suatu produk memiliki kualitas produk yang baik maka loyalitas merek yang dihasilkan akan tinggi bagi kosmetik Wardah di Surabaya Selatan.

Hal ini menunjukkan bahwa produk yang memiliki kualitas baik, tahan lama, dan tidak berbahaya, sehingga konsumen akan mengulang atau membeli kembali kosmetik wardah. Terlihat dari hasil kuisioner bahwa variabel kualitas produk yang terjadi pada kosmetik Wardah banyak diminati oleh konsumen karena memiliki kualitas yang baik pada produknya yaitu kualitas produk yang tidak berbahaya dan memiliki jangka waktu yang lama. Sehingga kualitas produk baik maka loyalitas merek akan tinggi.

Menurut Mowen (2011: 90). Kualitas produk adalah keseluruhan proses evaluasi kepada pelanggan untuk meningkatkan kinerja suatu produk atau layanan. Hasil penelitian ini sejalan dengan penelitian sebelumnya oleh Olivia Dinar Oktadiani, Nur Laily (2020) yang menjelaskan bahwa kualitas produk berpengaruh positif dan signifikan terhadap loyalitas pelanggan.Hasil penelitian ini menunjukkan bahwa kualitas produk berpengaruh positif dan signifikan terhadap loyalitas merek produk kosmetik Wardah di Surabaya Selatan. 


\section{E. PENUTUP}

Kesimpulan

Berdasarkan hasil pembahasan di atas, maka dapat ditarik kesimpulan sebagai berikut:

1. Citra merek berpengaruh positif dan signifikan terhadap loyalitas merek produk kosmetik Wardah di Surabaya Selatan.

2. Kualitas produk berpengaruh positif dan signifikan terhadap loyalitas merek produk kosmetik Wardah di Surabaya Selatan.

\section{F. DAFTAR PUSTAKA}

Bilson, Simamora. 2013. Memenangkan Pasar dengan Pemasaran Efektif dan Profitable. Jakarta : PT. Gremedia Pustaka Utama.

Febriyanto Ngabis, dkk 2021. Pengaruh Citra Merek (brand image) dan kepercayaan merek (brand trust) terhadap loyalitas merek (brand loyalty) pada produk air minum dalam kemasan merek aqua (studi kasus pada konsumen AMDK merek aqua di kota gorontalo). Jurnal ISSN 2622-1616, Vol 4, No 1. 2021.

Kotler, Kevin Lane . 2013. Strategic Brand Management (Building, Measuring, and Managing Brand Equity), Fourth Edition. New Jersey : Practic Hall

Kotler,Philip \& Gary Armstrong. 2014. Principle Of Marketing. $15^{\text {th }}$ edition. New Jersey : Pearson Printice Hall.

Kotler, Phillip dan Keller, Kevin. 2016. Marketing Management 15 edition. New Jersey : Pearson.

Putri, E.A., Apriatni, E.P., dan Wijayanto, A. 2013. Pengaruh Perluasan Merek dan Kualitas Produk terhadap Keputusan Pembelian Sampo Dove di Semarang. Dipenogoro Journal of Social and Politic, pp:1-6.Rangkuti, Freddy. 2013. The Power Of Brands. Jakarta: PT. Gremedia Pustaka Utama.

Ridho, Suharyono (2017). Pengaruh kualitas Produk Terhadap pada Brand Image dan Dampaknya Pada Kepuasan Pelanggan (Survei pada Pelanggan kartu prabayar Simpati, Kota Malang). Jurnal Administrasi Bisnis (JAB)|Vol. 53 No. 1.

Salim, Fanny Fibriyanti., \& Dharmayanti, Diah. 2014. Pengaruh Brand Image dan Perceived Quality Terhadap Kepuasan dan Loyalitas Pelanggan Mobil Toyota di Surabaya. Jurnal Manajemen Pemasaran Petra, 2(1): 1-8.

Santoso, Singgih. 2014. Statistik Parametrik Edisi Revisi. Jakarta: Elex Media Komputindo.

Schiffman, 1.G. dan Kanuk, Leslie L. 2013. Consumer Behavior. 8th dition. New Jersey : Practic Hall

Sondakh (2014). Kualitas Layanan, Citra Merek Dan Pengaruhnya Terhadap Kepuasan Nasabah Dan Loyalitas Nasabah Tabungan (Studi Pada Nasabah Taplus BNI Cabang Manado). Jurnal Riset Bisnis dan Manajemen Vol.3, No.1, 2014:19-32.

Sugiyono. 2015. Metode Penelitian Kuantitaf Kualitatif R\&B. Bandung : Alfabeta.

Suwarni. 2011. Pengaruh Kualitas Produk dan Harga terhadap Loyalitas. Jurnal Ekonomi Bisnis. (16)1, pp:76-84.

Non Buku

www.topbrand-awaard.com

https://www.wardahbeauty.com/ 